\title{
Land Management for Sustainable Agriculture Under Climate Change in the Congo-Basin Countries of Central Africa
}

\author{
Ernest L. Molua ${ }^{1}$ \\ ${ }^{1}$ Department of Agricultural Economics and Agribusiness, Faculty of Agriculture \& Veterinary Medicine, \\ University of Buea, Cameroon \\ Correspondence: Ernest L. Molua, Department of Agricultural Economics and Agribusiness, Faculty of \\ Agriculture \& Veterinary Medicine, University of Buea, Cameroon. Tel: 237-9949-4393. E-mail: \\ emolua@cidrcam.org
}

Received: June 27, 2014 Accepted: July 30, 2014 Online Published: October 22, 2014

doi:10.5539/enrr.v4n4p178 URL: http://dx.doi.org/10.5539/enrr.v4n4p178

\begin{abstract}
Degradation of ecosystem services is evident in the Congo-Basin Countries of Central Africa. This paper examines land management for sustainable agriculture in the context of environmental change and climatic stress. The interaction between drivers of change, institutional arrangements and the actions of stakeholders are discussed to highlight local, regional and global benefits of sustainable agricultural land management. The paper notes that tenure security has to be at the heart of any agricultural development plans, and managing agricultural land in the context of environmental change and climate stress requires that land managers ensure the long-term productive potential. It is recommended that land-based entrepreneurs adopt land use systems which enable them to maximize the economic and social benefits from land while enhancing the ecological support functions of land resources. The paper concludes that land policy reforms which aim to promote sustainable land management should address issues related to land rights and institutions driven by inefficient and inequitable historical legacies, including access to land by women, indigenous groups; as well the inefficiencies and inequities that arise from poor legal and administrative systems.
\end{abstract}

Keywords: central African sub-region, agricultural land management, sustainable agriculture

\section{Background}

The Congo Basin, acknowledged as the second largest tropical rainforest on earth and the lungs of Africa, has a rich and diverse ecosystem which provides food, fresh water, shelter and medicine for tens of millions of people, as well as home to some critically endangered species. Its rivers, swamps, trees and savannahs significantly contribute to sustain life across the whole planet, playing a critical role in regulating the global climate for the benefit of the entire biosphere. Agriculture is the economic foundation of the Central African countries within the Congo Basin, employing about 60 percent of the workforce and contributing an average of 30 percent of gross domestic product. However, agricultural growth rates have stagnated and food insecurity remains a concern, with malnourishment significant in some countries (Bush, 2010). With the exception of few countries such as Gabon and Equatorial Guinea that rely on oil to drive their economies, the predominant livelihood activity in the subregion is smallholder semi-subsistence farming. Households rely on cash and subsistence incomes from a number of sources that include rainfed cultivation, livestock production and non-timber forest exploitation. The agricultural activities are affected not only by unfavourable climatic conditions, poor markets and infrastructure services, but also by unfavourable physical conditions (poor soils, land degradation caused by cultivation on sloping land, deforestation) (Aklilu \& de Graaff, 2007).

Some thousands of hectares of land is used for crop production in Central Africa, millions hectares more of potentially arable land competes with other land uses for infrastructure and human settlement along with land set aside for, e.g. forest ecosystems in natural reserves. Figure 1 shows the dominant ecosystem classes and agricultural production potentials across Africa. We note for Central Africa sub-region the domination of forest, woodland and grassland particularly suitable for rainfed production of various crops (e.g. food, fibre, fodder crops and pasture grasses) under different input and management techniques. Compared to other regions in Africa, Central Africa's intensive cropland is largely across Cameroon, Central African Republic and Burundi, with unused potential in the other countries in the sub-region. Millions of hectares of land in the sub-region has 
cultivation potential (whether very suitable, suitable or moderately suitable) required for the cultivation of typical crops such as grain maize. However, this suitability coincides with land dominantly classified as forest ecosystem. For a country like Gabon, this is important where a significant proportion of prime arable land is under protected forests and conservation programmes, thus constraining farmers' access to land. Overall, however, the potential of Central Africa subregion demonstrates the feasibility of intensifying production, regenerating and preserving soils, and maintaining biodiversity through agroecological technologies and indigenous methods which enable farmers to take advantage of local resources and reduce dependency on external capital-intensive inputs.

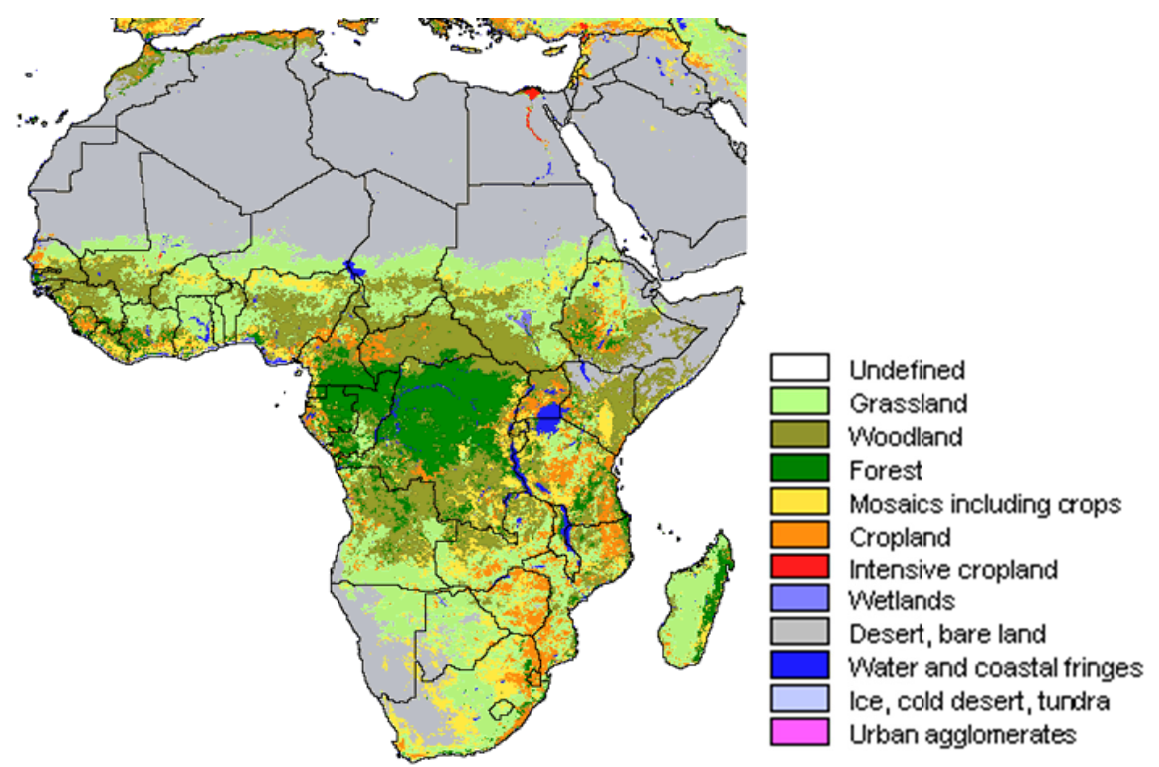

Figure 1. Dominant ecosystem classes across Africa (Fischer et al., 2000)

This paper examines land management for sustainable agriculture under climate change in the Congo-Basin Countries of Central Africa. This is deemed important because of the dominant view that land reforms could enhance security of tenure and promote investment in agriculture, thus lead to increased growth and development (Byres, 2004; Barrows \& Roth, 1990). However, such land reform programmes failed to develop the smallholder agriculture sector. The coexistence of various forms of tenure in the countries - state, communal, customary, individual - suggests the need to review and develop complex policy and analytic models focusing on the pertinent relationship between land tenure and sustainable development (DFID, 1999). The rest of this paper examines land-use and tenure issues in the sub-region in section two, it then reviews the challenges of agricultural land management under climatic change in section three and makes recommendations, in section four, for some policy safeguards for sustainable agricultural land capital management for countries in the sub-region.

\section{Land Use and Tenure for Agricultural Development}

When considering major crop types, particularly cereals; about $40 \%$ of the Central African land surface can be regarded as suitable for crop cultivation. Despite this optimistic aggregate picture, there are hotspots such as in Northern Cameroon and Chad where the rain-fed cultivation potential is nearly fully exhausted or has already been exceeded, and there is need for irrigation. Table 1 shows the per capita land in use for cultivation and net rain-fed cultivation potential for cereals with projected population levels between 1995 and 2050. Contemporary Land use for cultivation in the middle belt of Africa is $3.8 \%$ compared to rainfed net potential land of $40.9 \%$. The arable land per person is about $0.3 \mathrm{ha}$, the world average in 1995 being about 0.26 ha/person for a world population of almost 5.7 billion people. High potential land is estimated to cover $3.22 \mathrm{ha} /$ person and $0.97 \mathrm{ha} /$ person in 2050 . Overall, land in use in Africa for cultivation averages 6.6\% compared to global average of $11.2 \%$ of the total land. About $26.65 \%$ of African land is high potential rain-fed land, higher than the world average of $21.8 \%$. The per capita land use for suitable land in Africa was $1.12 \mathrm{ha} /$ person in 1995 and projected to decline to $0.45 \mathrm{ha} /$ person in 2050 . This compares favourably with the global figure of 0.51 ha/person in 1995 and expected to decline to 0.33 ha/person in 2050. This suggests a considerable availability of resources suitable for agricultural uses in Africa, including Central Africa. This, nonetheless, highlights the need for a land management policy which promotes efficient input use and technology leading to higher average per hectare output in lands currently under exploitation, and more 
effort to better manage competition with other non-agricultural uses with safeguards for bio-diversity and the carbon cycle.

Table 1. Per capita land in use for cultivation and net rain-fed cultivation potential for cereals, populations of 1995 and projected populations in 2050

\begin{tabular}{lcccccccccc}
\hline & $\begin{array}{c}\text { Population } \\
\text { Region }\end{array}$ & $\begin{array}{c}\text { Total } \\
\text { lmillion) }\end{array}$ & $\begin{array}{c}\text { Land in use } \\
\text { forcultivation } \\
(1994-96)\end{array}$ & $\begin{array}{c}\text { Rain-fed } \\
\text { VS+S+MS } \\
\text { net potential land } \\
\text { (mixed input) }\end{array}$ & $\begin{array}{c}\text { Per Capita } \\
\text { land use } \\
\text { (ha/pers.) }\end{array}$ & $\begin{array}{c}\text { Per Capita } \\
\text { VS+S+MS } \\
\text { land } \\
\text { (mixed input) }\end{array}$ \\
\cline { 2 - 13 } & 1995 & 2050 & $\left(10^{6}\right.$ ha) & $\left(10^{6}\right.$ ha) & $\%$ & $\left(10^{6}\right.$ ha) & $\%$ & $1994-96$ & 1995 & 2050 \\
\hline Eastern Africa & 219.5 & 593 & 639.5 & 46.0 & 7.2 & 237.4 & 37.1 & 0.21 & 1.08 & 0.40 \\
Middle Africa & 83.3 & 274.6 & 657.1 & 24.8 & 3.8 & 268.5 & 40.9 & 0.3 & 3.22 & 0.97 \\
Northern Africa & 157.8 & 303.2 & 794.1 & 44.1 & 5.6 & 92.9 & 11.7 & 0.28 & 0.59 & 0.30 \\
Southern Africa & 47.3 & 65.5 & 266.4 & 17.4 & 6.5 & 28.4 & 10.6 & 0.37 & 0.60 & 0.43 \\
Western Africa & 209.4 & 526.3 & 633.0 & 65.4 & 10.3 & 174.3 & 27.5 & 0.31 & 0.83 & 0.33 \\
Africa & 717.3 & 1762.7 & 2990.1 & 197.7 & 6.6 & 801.4 & 26.8 & 0.28 & 1.12 & 0.45 \\
Developing countries & 4510.8 & 7746.6 & 8171.5 & 909.6 & 11.1 & 1971.5 & 24.1 & 0.2 & 0.44 & 0.25 \\
Developed countries & 1171.7 & 1155.0 & 5228.0 & 595.5 & 11.4 & 952.5 & 18.2 & 0.51 & 0.81 & 0.82 \\
World & 5682.4 & 8901.6 & 13399.5 & 1505.2 & 11.2 & 2924.0 & 21.8 & 0.26 & 0.51 & 0.33 \\
\hline
\end{tabular}

Notes: VS = very suitable, $\mathrm{S}=$ suitable, $\mathrm{MS}$ = moderately suitable. Calculation of net rain-fed land with cultivation potential makes an allowance for infrastructure and settlement, taken to be $10 \%$ in 1995 and $15 \%$ in 2050 of the gross suitable area. Source: Fisher et al. (2000). http://www.iiasa.ac.at/Research/LUC/GAEZ/index.html

Figure 2 shows the agricultural area relative to the total national land area for selected countries in the region from 1965 to 2009 . For Chad more than $35 \%$ of country land area is utilized as agricultural land, and almost $30 \%$ for the Republic of Congo, $20 \%$ for Gabon and more than $15 \%$ for Cameroon. This agricultural land is likely to expand in order to satisfy the needs of the rapidly growing population. Such expansion for food and raw material needs may transform the natural ecosystem of the region, particularly the Congo Basin which is of global significance in its climate change mitigation potentials. Combining the information emanating from figures 1 and 2 and table 2, we may conclude that the way land resource is used in the subregion could be decisive for future social and economic well-being as well as for the sustained quality of land resources in Central Africa. Therefore, if more production is required from the existing land resource while cultivable areas are being shifted towards non-agricultural uses, land policy and land administration must play important roles in land use dynamics through suitable institutional mechanisms, scientific management, conservation and development of land resources.

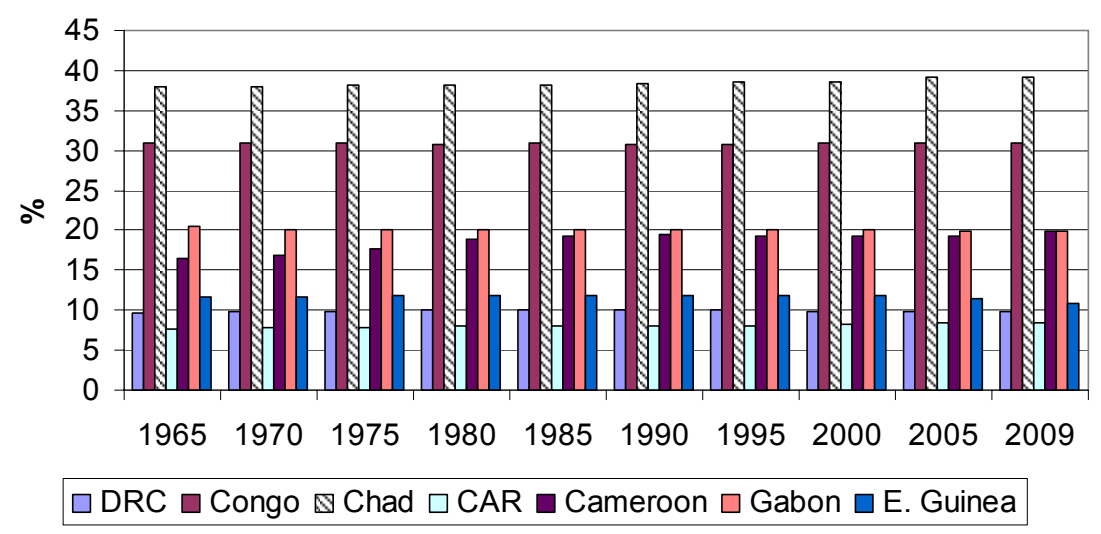

Figure 2. Agriculture area per unit of national land area (\%) 
Conservation and development of land resources are important processes that determine the value and total economic importance of African land. Whether it is the scramble for African land or the intensification of agriculture, the over-exploitation of soil resources and the expansion into marginal lands has led to soil fertility depletion (Pasquini \& Alexander, 2005). Fertility depletion is common in North Cameroon and Chad, whilst the 'land grab' is significant in Southern Cameroon and the Democratic Republic of Congo. The limited adoption of fertilizer replenishment strategies and soil and water conservation measures and decline in the use and length of fallow periods is impacting negatively on their agricultural production (Aklilu \& de Graaff, 2007; Scoones et al., 1996). Land grab means that prime agricultural land carved out deprives the community land resources (Deininger, 2011). In addition to this challenge, for smallholder farmers, the prevailing global financial crisis and low farm returns has meant a decline in farm input investment, including fertilizers, seeds, and technology adoption against soil degradation. This has significant impact on agriculture and poverty reduction (Griffin et al., 2002). For the poorest people, GDP growth originating in agriculture is more effective in raising incomes of extremely poor people than GDP growth originating outside the sector. Therefore, the land question in relation to access and management is an important problem to resolve if these countries and their rural peasantry are to emerge from economic and social crisis.

Tenure security which has to be at the heart of any agricultural development plans, is achieved when property rights are clarified and widely acknowledged (Andersson, 2007). In most cases, progress will consist of (a) the reconciliation of diverse and conflicting claims, (b) the clarification of latent or overlapping rights in resources, and (c) the reconciliation of statutory and customary regimes. The question of considering customary rights in sustainable land management has been identified in almost all the countries in Central Africa. Currently, customary land tenure is not adequately recognized in the majority of Central African countries. However, in reality most people in the region occupy their land under a customary system. This means absence of formal tenure rights and consequently insecurity of land tenure. Concerns about population growth and pressure on land in urban areas and coastal zones have been raised in countries like Cameroon, Congo, Gabon and Equatorial Guinea (Gilland, 2002; Pender, 1998). Forced evictions, expropriations and related land issues are also critical issues in Central Africa.

Pender et al. (2006) and Andersson (2007) have shown that property rights and secure access to and control over land and natural resources can generate critical incentives for conservation and sustainable use, management, and governance of natural resources. Insecure, unclear, limited or short-term property rights can inhibit sustainable land and natural resource management and discourage stakeholders from acting as long-term stewards of land and natural resources (Adesina \& Baidu-Forson, 1995). Property rights affect outcomes such as agricultural productivity, household income, and land degradation (Mbaga-Semgalawe \& Folmer, 2000). This is captured in Figure 3 which shows how agricultural production and land conditions are affected by land management practices, including both private decisions made by farm households and collective decisions made by groups of farmers and communities. Pender et al. (2006) notes that farm households may make decisions about land use (e.g. grazing land), the crop types to plant, the amount of labor to use, and the types and amounts of inputs, investments, and agronomic practices to use to conserve soil and water, improve soil fertility or reduce pest losses. Communities also can influence land management through their collective decisions. They may make investments on communal land areas (e.g. erosion controls on degraded lands, tree planting) or private lands (e.g. drainage investments as part of watershed conservation and development efforts) or regulate use of communal land (e.g. restrictions on use of grazing areas) or private lands (e.g. bylaws limiting burning or cutting of trees). Agricultural income strategies and land management decisions are affected by these different factors operating at different scales (Pender, 1998; Pagiola, 1996). Local institutions also have important influences on income strategies and land management. In much of Central Africa, customary land tenure institutions determine what land use rights and land management obligations farmers have, how secure those rights are, whether those rights may be transferred or used as collateral, how conflicts are resolved, and other questions. Such institutions can have substantial effects on land management by regulating land use. 


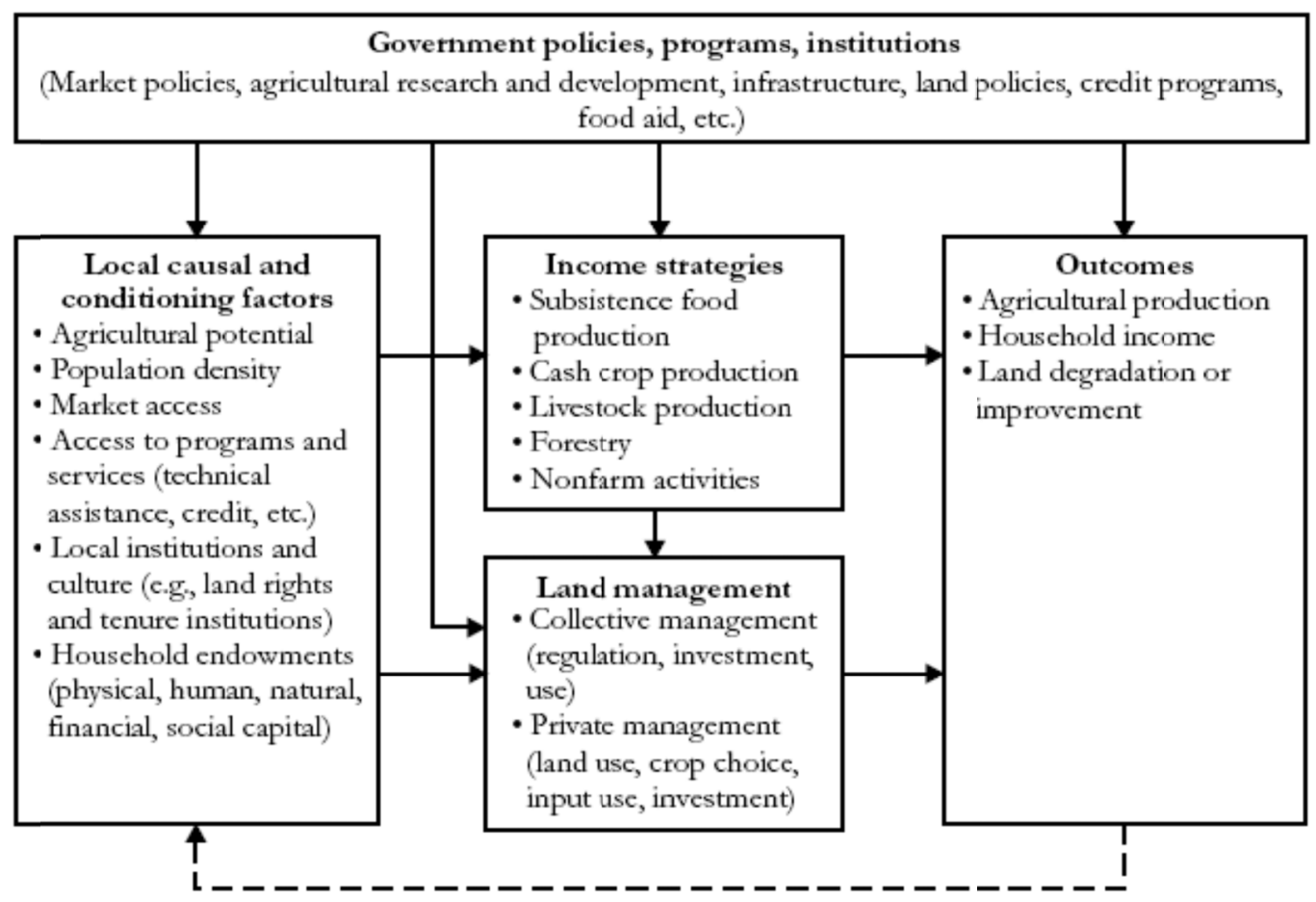

Figure 3. Income strategies and agricultural land management (Source: Pender et al., 2006)

\section{Agricultural Land and Environmental Stress Under Climate change}

Studies of anthropogenic biogeophysical climate change in the Congo basin point to a regional surface warming and a decrease in precipitation, largely as a consequence of tropical deforestation (Polcher \& Laval, 1994; McGuffie et al., 1995; Semazzi \& Song, 2001). Recently, Nogherotto et al. (2013) and Akkermans et al. (2014) show a strong spatial correlation between deforestation and global warming. Akkermans et al. (2014), for instance, reveal that countries in the Central Africa sub-region by 2050 will be an average of $1.4^{\circ} \mathrm{C}$ hotter than today as a result of global greenhouse gas emissions. Deforestation will add an extra $0.7^{\circ} \mathrm{C}$ to that figure. Their findings also show a strong spatial correlation between deforestation and global warming. In certain deforestation 'hot spots', increases caused by deforestation could rise to $1.25^{\circ} \mathrm{C}$, in addition to the warming caused by greenhouse gases.

Managing agricultural land in the context of environmental stress and climate change is therefore an imperative. This therefore requires that land managers use of land resources for the production of goods to meet changing human needs, while simultaneously ensuring the long-term productive potential of these resources and the maintenance of their environmental functions. This implies that land-based entrepreneurs should adopt land use systems that, through appropriate management practices, enable them to maximize the economic and social benefits from the land while maintaining or enhancing the ecological support functions of the land resources. In countries within Central Africa where the economy is heavily based on agriculture, development of the agricultural sector through sustainable land management could be the most efficient poverty reduction measure. Yet, agricultural expansion for food production and economic development which comes at the expense of soil, water, biodiversity or forests is highly vulnerable to prevailing environmental stress and climate change (Shiva, 2008; Scoones et al., 1996). In the face of ensuing climate change, the impacts may not be uniform in the sub-region since Central Africa is characterized by extreme ecological diversity, stretching from the north of Chad that is characterized by permanent drought and the humid forest in the equatorial region to the south of Gabon. Being a typical equatorial region on both sides of the equator, Central Africa hosts one of the world's richest forest biodiversity. Given its latitudinal position, the region therefore experiences the main ecosystems types of the continent. Three other ecological regions are found in the sub-region: the wooded savannah found mostly in Central African Republic, Cameroon and Angola; the arid region stretches from the $9^{\circ}$ north of the equator to the Chad-Libyan border; and the Sahelian region of Central Africa and Northern Cameroon that suffers from permanent drought with its consequences on livelihoods. 
The fragility of its ecology means that the region faces significant challenges from climate variability and change. Rainfall variability experienced in sub-Saharan Africa already has detrimental impacts on crop production and agriculture as a whole (Schlenker \& Lobell, 2010). Indeed, too much or too little water due to erratic rainfall and insufficient storage capacity wields adverse impacts on food security (Schmidhuber \& Tubiello 2007; Jones, 2003). Already, some farmers are experiencing more frequent and intense storms that cause erosion, rainwater run-off, and crop damage, while others experience more frequent droughts. At the same time rainfall patterns are becoming more variable with delayed onset and length of the rainy season, and in some cases, drought. These unpredictable patterns make it difficult for farmers to plan and manage their crops (Schmidhuber \& Tubiello, 2007). All these impact the total economic value of land.

Future climate change is widely predicted to impact on rainfall variability in sub-Saharan Africa, with the effect of increasing droughts and floods (Müller et al., 2011). Even using optimistic lower-end projections of temperature rise, climate change may reduce crop yields by $8-20$ percent by the 2050 s, with more severe losses in some regions (Schlenker \& Lobell 2010; Schmidhuber \& Tubiello, 2007). Warmer temperatures, more variable rainfall, and higher incidence of extreme events all magnify stresses on the farming systems. Increasing frequencies of heat stress, drought and flood events, will result in yet further deleterious effects on productivity and wellbeing (Patt et al., 2010). It is likely that price and yield volatility will continue to rise as extreme weather continues. In fact, world food prices for some of the main grain crops are likely to rise sharply half of the 21 st century, unlike the price declines witnessed in the 20th century (Rosegrant et al., 2001). This will have serious consequences on food security. Climate change will also impact on agriculture through effects on pests and disease. These interactions are complex and as yet the full implications in terms of productivity are uncertain. It is therefore essential for policy planners to find ways to cope with existing climate stressors, as well as other effects of future climate change. African producers have already developed a number of indigenous coping mechanisms to support survival in the face of climate variability. However, global climate change increases the risks that African farmers must efficiently manage, and policy makers must respond with the appropriate measures to facilitate adaptation required to uphold the value of land.

Fortunately, there are a range of land-based management practices and technologies that can be applied on-farm to increase agricultural resilience to climate stress. However, property rights and secure access to and control over land and natural resources can generate critical incentives for conservation and sustainable use, management, and governance of natural resources (Lapar et al., 1999; DFID, 1999). Insecure, unclear, limited or short-term property rights can thus inhibit sustainable land and natural resource management and discourage stakeholders from acting as long-term stewards of land and natural resources. Land tenure challenges are age-old and climate change simply exacerbates the situation. The uncertainty of future climate variability and change requires greater flexibility in all land-based production systems. Given the central role of user rights in those systems, land and resource tenure will likewise require greater flexibility, thus raising a critical policy matter for many countries to maintain flexibility in customary and statutory tenure systems. Tenure security will be a critical factor in providing the incentives for mitigating greenhouse gas emissions and adapting to climate change (Howden et al., 2007). Because climate-induced migrations (as already seen in northern Chad and northern Cameroon) could lead to social tensions, climate change will challenge institutions responsible for the governance of natural resources such as land to establish inclusive processes to negotiate claims, regulate disputes, and establish new tenure systems.

Effective response to the challenges of climate variability and change will require an ecosystem approach, working at the landscape level to increase productivity, enhance resilience to changing temperatures and rainfall patterns, and reduce greenhouse gas emissions that contribute to climate change. This means significant changes in agricultural practice in coming years, promoting and adopting ecological practices that can provide "no regrets" insurance against climate change, e.g. mulching of crops to allow more rain to soak into the soil, slow down how quickly that soil moisture evaporates, and reduce the erosion of soil into streams. Some other measures include intercropping to take advantage of different plants having different patterns of root growth and different needs for nutrients, less tillage of soil to boost fertility and health of soil over time while also reducing wind and water erosion of soil because it is less exposed, agroforestry of mixed food crops and trees for provisioning and environmental services including managing micro-climates and water management both in streams and on fields. These measures require secure unfettered access to land.

In semi arid zones such as in Northern Chad and other already degraded ecosystems such as through slash-and-burn agriculture in Southern Cameroon and Burundi, a range of well-established restoration and management options can improve human livelihoods, repair ecosystems, and increase the resilience of both people and landscapes to climate change. This will include the following at the farm-scale: soil and nutrient management (e.g. through conservation agriculture, improved application of fertilizers, and increasing fertility by integrating 
legumes into farming systems); water harvesting and use (e.g. capturing rainwater, retention of soil moisture and increasing water productivity through irrigation); integrated pest and disease management; resilient ecosystems (e.g. through farm management practices that reduce erosion and rainwater run-off, increase on-farm habitat for beneficial insects, pollinators and wildlife, sequester carbon, and reduce conversion of natural habitat to agriculture support ecosystem resilience across the landscape); genetic resources for climate resilient varieties; Harvesting, processing and supply chains that reduce post-harvest losses and preserve quantity, quality, and nutritional value of food products; and diversification to increase the efficiency of farming systems and build their resilience to climate change. A proactive land policy making process and efficient land administration service create incentive for adoption of better land management measures.

Therefore, an important challenge for governments and policy makers with respect to appropriate land management is to promote the adoption of these environmentally friendly practices, at the micro and macro-scales (World Bank, 2006). Figure 4 below contextualizes the role of government in a framework for sustainable land management and agricultural transformation. Considerations in the schema include: adopting an ecosystem approach with cross-sectoral coordination and collaboration at the landscape scale as being essential to adapt to climate stresses; scaling up effective climate-smart practices; ensuring institutional, technical, and financial support for small-holder; reducing data, knowledge and technology gaps which exist and should be addressed to support improved technologies, methodologies, and climate resilient varieties; and harmonization of climate change, agriculture and food security policies is required at the national, regional and international levels (Schmidhuber \& Tubiello, 2007; Holden et al., 2006).

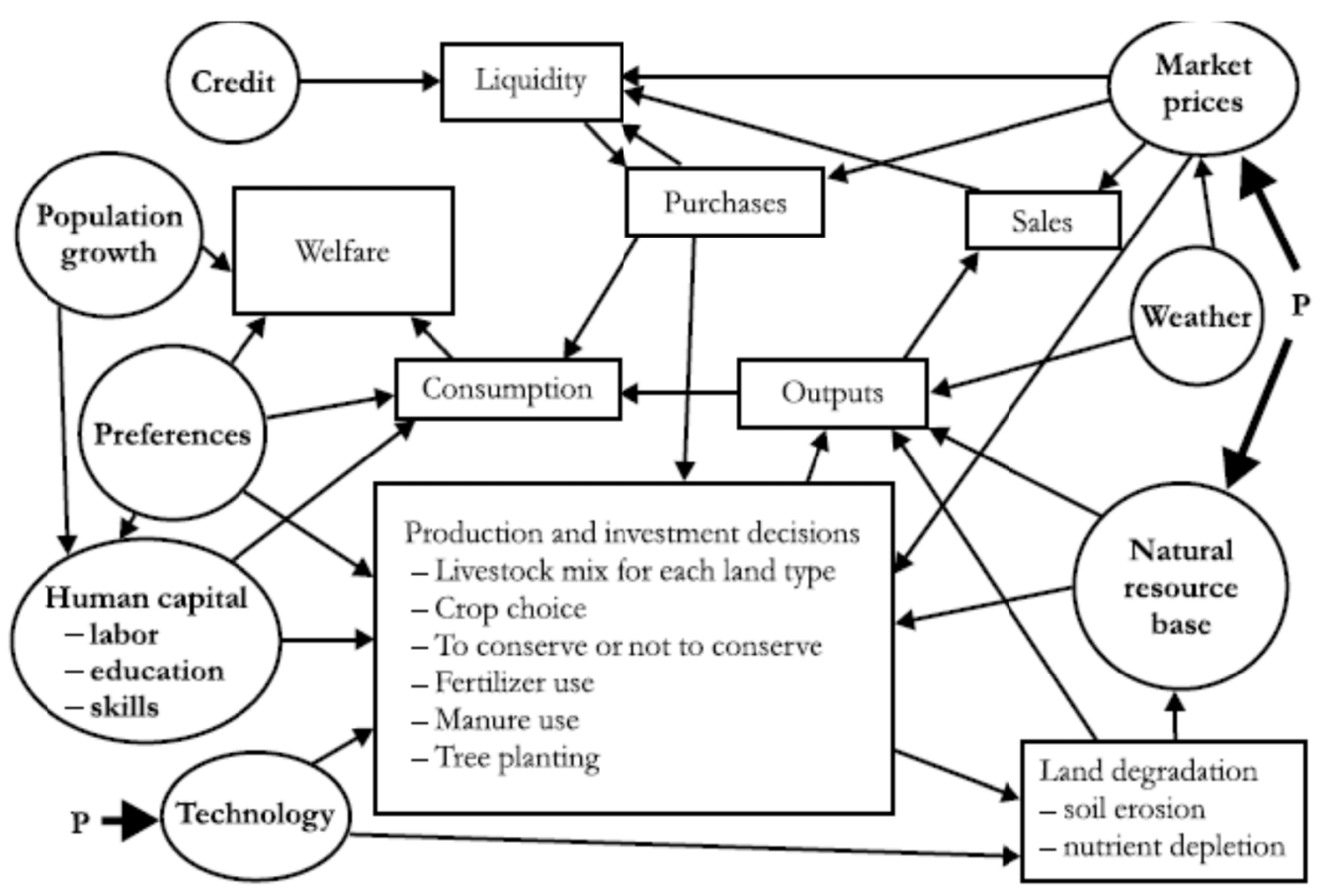

Figure 4.Household Dynamic Interaction for Sustainable Land Management,and Food Security

(Source: Holden et al., 2006)

In essence, the farm-level micro-scale challenges highlight the need to get land policy right and ensure better land administration for comprehensive access and user rights to land. As shown in Figure 3 households maximize their welfare subject to many constraints such as land degradation in the form of soil erosion and soil nutrient depletion. This may also include weather risk which affects production as well as prices (Molua, 2011; Pagiola, 1996). Any compromise through non-existent land policy or ineffective land administration jeopardizes important household production and consumption decisions. These decisions are based on expectations about prices and output and the risk involved, and thus need flexible access to agricultural land to be able to respond and minimize risks and maximize opportunities (Mbaga-Semgalawe \& Folmer, 2000). Given the current situation where agricultural practitioners largely identify access to productive land as a constrain, the rising population growth which already 
strain land uses may also affect household welfare as more people have to share the outcome of a constant land area which is also affected by land degradation (Gilland, 2002; Pender, 1998). Holden et al. (2006) posit that this may lead to a Malthusian development path, and the ensuing poverty-environment trap can only be broken through availability of new technologies, improved access to markets, and better investment opportunities which all require unfettered access to prime productive land.

\section{Policy Safeguards for Sustainable of Agricultural Land Capital Management}

While the specific challenges to land capital management across countries in the central African sub-region are diverse, however, common among them is the concern about environmental sustainability and the need for successful land management interventions being increasingly recognized in national development plans and poverty reduction strategies. Translating this recognition into effective policies or programmes in the face of climate change is the Achilles heel to sustainable land management in the sub-region. Any policy to address land capital management for sustainable agriculture in the context of environmental change must capture three key principles, which include: (1) integrated use of natural resources at ecosystem and farming systems levels; (2) multilevel and multi-stakeholder involvement; and (3) targeted policy and institutional support including development of incentive mechanisms for land-user-driven and participatory approaches in sustainable land management and adoption at the local level.

Land policy reforms which aim to promote sustainable land management should address issues related to land rights and institutions driven by inefficient and inequitable historical legacies, including access to land by women, poor people, indigenous groups; as well the inefficiencies and inequities that arise from poor legal and administrative systems. This must also take cognizance of old and new challenges that arise in the context of increasing scarcity of land; and the increasing competition for their use from urbanization, environmental services and biofuels. Addressing the inequities, particularly related to gender is important for sustainable land management, not only because women are significant crop producers in the sub-region, but also that there are both economic and social benefits when women have secure access to valuable land. Hence, institutions for sustainable land management must take the gender question serious. Property rights in land - whether customary, formal, or religious - provide economic access to key markets and social access to non-market institutions such as household and community-level governance structures (Adesina \& Baidu-Forson, 1995). Secure land rights confer direct economic benefits because land: (1) is a key input into agricultural production and enterprise development; (2) can be used as a source of income from rental or sale; (3) can provide collateral for credit where strong, well-regulated land markets exist; and (4) can increase the capacity to invest in coping mechanisms and adaptation practices to secure livelihoods. Without secure land rights, women are less able to take advantage of changes that may result from stresses such as climate change. Women may not fully reap these benefits if they do not have legal and socially-recognized rights to individually- or jointly-held land (Stockbridge, 2007). This therefore calls for proactive land policy and better functioning land administration. An effective land administration will correct imbalances by safeguarding active land markets, speeding the issuance of land titles, and accelerating plot surveys, implement land resettlement for displaced communities e.g. from large-scale land grabbing. These may not only lead to tenure security but also improve the efficiency of land management (Basu, 1996). In other words, reliable institutions are needed to promote timely adjudication and land registration, strengthening land administration institutions and organizing the national land register (Atwood, 1990).

Land policy should not only be limited to addressing inaccessibility to land or landlessness. Attention should be given to the need to increase productivity per unit of land through better land utilization (Migot-Adholla et al., 1991). Better land utilization will require increased investment in agriculture, from both public and private sectors (Shiva, 2008). These investments are sustainable if they land-user driven at the local level. Farmers will therefore require incentives to invest in land improvements, drainage and irrigation, which are provided by increasingly secure ownership rights. To provide these rights and incentives, policy must encourage communal right systems which allocate inheritable usufruct rights, first to homesteads and nearby fields, then to the right to resume fallowed land, and any areas into which farmers have invested by planting trees, or investing in soil conservation, drainage and irrigation. The strength of communal rights systems is that they restrict sales to outsiders of the community, or subject them to community approval. Studies in Africa have shown that customary systems can provide sufficient tenure security for investment (Bruce \& Migot-Adholla, 1994).

The vast majority of investment in agriculture in the sub-region is from private domestic sources. Public investment in individual countries is historically small. National and local level governments can enact and implement policies that encourage access of smallholders to additional sources of funding, including microcredit, revolving grants, and crop insurance. Remittances from abroad and international donor investment are also important funding sources. Local civil society organizations, such as farmer cooperatives and water user 
associations, must have access to financing not only to cover capital costs for irrigation infrastructure, per se, but also for operation and maintenance of these systems.

Capacity building is thus imperative, and this should be promoted by governmental and non-governmental institutions, particularly the international NGOs and UN-based system organizations with their enormous financial and intellectual capital. Support to countries in the sub-region from these organizations should be on a wide range of complementary approaches, through training, information, communications, tools and equipment, advisory services for institutional strengthening, policy reforms and national programming. Common among countries in the sub-region is ineffective underperforming agricultural research institutions. Significant achievements could be made by building the capacities of local agricultural research institutes with national research mandate to promote the sustainable use and management of agricultural land and natural resources. Such centres with objectives underpinned in knowledge generation on agricultural natural resources and agro-ecosystems as well as research application; innovative technology development; and technology transfer, must conduct research, drive technology development and transfer in order to promote agriculture and related industries; and ensure natural resource conservation for poverty alleviation and a better quality of life.

\section{Conclusion}

Land is a primary asset at the centre of Central Africa's development challenge, as three-quarters of its people depend on it directly for their subsistence. Land degradation thus increases poverty and vulnerability, impedes agricultural growth, and contributes to social tensions as well as threatening biodiversity. This dominance of land as a source of wealth for economies in the Central African sub-region makes land policy especially politically sensitive and effective policies need to be based on an understanding of the political economy context. For the sub-region, environmental change, climate and population pressure are important in explaining land use, particularly the area allocated for agriculture to promote production of higher-value enterprises. Land policies, therefore, need to effectively accommodate not only customary land tenure into national legislation while improving the ability of disadvantaged groups such as women to own land within formal and customary systems where they often lack rights, but also adaptation to climate change. It is acknowledged that for Central Africa to achieve its development goals, climate change adaptation is a priority. An effective land policy and land administration will provide support to the implementation of adaptation measures that enhance agriculture and peoples' resilience for increased food security. This entails clarifying not only existing tenure of multiple users of the land, but also helping stakeholders negotiate new rules of resource access and use in the face of climate-induced disturbance to the status quo.

\section{References}

Adesina, A. A., \& Baidu-Forson, J. (1995). Farmers' perceptions and adoption of new agricultural technology: Evidence from analysis in Burkina Faso and Guinea, West Africa. Agricultural Economics, 13, 1-9.

Akkermans, T., Wim, T., \& Van Lipzig, N. P. M. (2014). The Regional Climate Impact of a Realistic Future Deforestation Scenario in the Congo Basin. Journal of Climate, 27, 2714-2734. http://dx.doi.org/10.1175/JCLI-D-13-00361.1

Aklilu, A., \& de Graaff, J. (2007). Determinants of adoption and continued use of stone terraces for soil and water conservation in an Ethiopian highland watershed. Ecological Economics, 61, 294-302.

Andersson, J. A. (2007). How much did property rights matter? Understanding food insecurity in Zimbabwe: a critique of Richardson. African Affairs, 106(425), 681-690.

Atwood, D. A. (1990). Land Registration in Africa: The Impact in Agricultural Production. World Development, 18(5): 659-71.

Barrows, R., \& Roth, M. (1990). Land Tenure and Investment in African Agriculture: Theory and Evidence. Journal of Modern African Studies, 28(2), 265-297.

Basu. (1996). The Market for Land: An Analysis of Interim Transactions. Journal of Development Economics, 20(1), 163-177.

Bush, R. (2010). Food Riots: Poverty, Power and Protest. Journal of Agrarian Change, 10(1), 119-29.

Byres, T. J. (Ed.). (2004). Redistributive Land Reform Today. Journal of Agrarian Change, 4(1-2).

DFID. (1999). Land Rights and Sustainable Development in Sub-Sahara Africa: Lessons and Ways Forward in Land Tenure Policy. In African Nations, 16-19 February 1999, UK. Department for International Development, London. 
Fischer, G., van Velthuizen, H., Nachtergaele, F., \& Medow, S. (2000). Global Agro-Ecological Zones (Global AEZ) 2000. Food and Agriculture Organization of the United Nations (FAO) and the International Institute for Applied Systems Analysis (IIASA), Rome, Italy / Laxenburg, Austria. Retrieved from http://www.iiasa.ac.at/Research/LUC/GAEZ/index.html

Gilland, B. (2002). World Population and Food Supply: Can Food Production Keep Pace with Population Growth in the Next Half-century? Food Policy, 27(1), 47-63.

Griffin, K., Khan, A., \& Ickowitz, A. (2002). Poverty and the Distribution of Land. Journal of Agrarian Change, 2(3), 279-330.

Holden (2006). Policies for Poverty Reduction, Sustainable Land Management, and Food Security: A Bioeconomic Model with Market Imperfections. In J. Pender, F. Place, \& S. Ehui (Eds.), Strategies for Sustainable Land Management in the East African Highlands (Washington, DC: International Food Policy Research Institute, pp. 333-356).

Howden, S. M., Soussana, J. F., Tubiello, F. N., Chhetri, N., Dunlop, M., \& Meinke, H. (2007). Adapting agriculture to climate change. Proceedings of the National Academy of Sciences, 104(50), 19691-19696.

Lapar, M., Lucila, A., \& Pandey, S. (1999). Adoption of soil conservation: The case of the Philippine uplands. Agricultural Economics, 21, 241-256.

Mbaga-Semgalawe, Z. M., \& Folmer, H. (2000). Household adoption behavior of improved soil conservation: The case of the North Pare and West Usambara Mountains of Tanzania. Land Use Policy, 17, 321-336.

McGuffie, K., Henderson-Sellers, A., Zhang, H., Durbidge, T., \& Pitman, A. (1995). Global climate sensitivity to tropical deforestation. Global Planet. Change, 10, 97-128. http://dx.doi.org/10.1016/0921-8181(94)00022-6

Migot-Adholla, S. E., Hazel, P., Beroit, B., \& Place, F. (1991). Indigenous Land Rights Systems in sub-Saharan Africa: A Constraint on Productivity. World Bank Economic Review, S(1), 155-173.

Molua, E. L. (2011). Farm income, gender differentials and climate risk in Cameroon: typology of male and female adaptation options across agroecologies. Sustainability Science, 6(1), 21-31. http://dx.doi.org/10.1007/s11625-010-0123-z

Müller, C., Cramer, W., Hare, W. L., \& Lotze-Campen, H. (2011). Climate change risks for African agriculture. Proceedings of National Academy of Sciences of the United States, 108(11), 4313-4315.

Nogherotto, R., Coppola, E., Giorgi, F., \& Mariotti, L. (2013). Impact of Congo Basin deforestation on the African monsoon. Atmospheric Science Letters, 14(1), 45-51. http://dx.doi.org/10.1002/as12.416.

Pagiola, S. (1996). Price policy and returns to soil conservation in semi-arid Kenya. Environmental and Resource Economics, 8(3), 225-271.

Pasquini, M. W., \& Alexander, M. J. (2005). Soil fertility management strategies on the Jos Plateau: the need for integrating 'empirical'and 'scientific'knowledge in agricultural development. The Geographical Journal, $171(2), 112-124$.

Patt, A. G., Tadross, M., Nussbaumer, P., Asante, K., Metzger, M., Rafael, J., ... \& Brundrit, G. (2010). Estimating least-developed countries' vulnerability to climate-related extreme events over the next 50 years. Proceedings of the National Academy of Sciences, 107(4), 1333-1337.

Pender, J. L. (1998). Population growth, agricultural intensification, induced innovation and natural resource sustainability: An application of neoclassical growth theory. Agricultural Economics, 19(1), 99-112.

Pender, J., Ehui, S., \& Place, F. (2006). Conceptual framework and hypotheses. In J. Pender, F. Place, \& S. Ehui (Eds.), Strategies for sustainable land management in the East African highlands (pp. 31-58).

Pender, J., S. Ehui, and F. Place, 2006. 'Conceptual Framework and Hypotheses.' In: Pender, J., F. Place and S. Ehui (eds.), Strategies for Sustainable Land Management in the East African Highlands (Washington, DC: International Food Policy Research Institute, pp. 31-58).

Polcher, J., \& Laval, K. (1994). The impact of African and Amazonian deforestation on tropical climate. Journal of Hydrology, 155(3), 389-405. http://dx.doi.org/10.1016/0022-1694(94)90179-1

Rosegrant, M. W., Paisner, M. S., Meijer, S., \& Witcover, J. (2001). 2020 Global food outlook: Trends, alternatives, and choices (Vol. 11). Intl Food Policy Res Inst.

Schlenker, W., \& Lobell, D. B (2010). Robust negative impacts of climate change on African agriculture. Environmental Research Letters, 5, 1-8. http://dx.doi.org/10.1088/1748e9326 
Schmidhuber, J., \& Tubiello, F. N. (2007). Global food security under climate change. Proceeding of National Academy of Sciences of the United States, 104, 19703-08.

Scoones, I., Reij, C., \& Toulmin, C. (1996). Sustaining the Soil: Indigenous Soil and Water Conservation in Africa. London: IIED Issue Paper 57.

Semazzi, F., \& Song, Y. (2001). A GCM study of climate change induced by deforestation in Africa. Climate Res., 17, 169-182. http://dx.doi.org/10.3354/cr017169

Shiva, V. (2008). Soil Not Oil: Climate Change, Peak Oil and Food Insecurity. London: Zed Books.

The World Bank. (2006). Sustainable Land Management. Challenges, Opportunities, and Trade-offs. Washington, DC.

\section{Copyrights}

Copyright for this article is retained by the author(s), with first publication rights granted to the journal.

This is an open-access article distributed under the terms and conditions of the Creative Commons Attribution license (http://creativecommons.org/licenses/by/3.0/). 